\title{
Endothelin-like Immunoreactivity in Midgut Endocrine Cells of the Desert Locust, Locusta migratoria
}

\author{
Luis M. Montuenga, ${ }^{*}$ M. A. Prado, ${ }^{*}$ D. R. Springall,$\dagger$ J. M. Polak,$\dagger$ and \\ P. SESMA* \\ *Department of Cytology and Histology, University of Navarra, Pamplona, Spain; and tDepartment of \\ Histochemistry, Royal Postgraduate Medical School, London, United Kingdom
}

Accepted September 8, 1993

\begin{abstract}
Endothelin-1-like immunoreactivity has been found in endocrine cells of the midgut of the desert locust Locusta migratoria. Several antisera have been directed against the whole molecule and its C-terminal sequence. Endothelin-1-immunoreactive cells are present in the main region of the midgut (ventriculus) and in the midgut caeca but not in the ampullae through which the malpighian tubules drain. Endothelin-1-like immunoreactivity colocalizes with FMRFa immunoreactivity in the cells of the main region of the midgut but not in those in the midgut caeca. Endothelin-1-immunoreactive cells are present not only in adults but also throughout the five instars of posthatching development. 1994 Academic Press, Inc.
\end{abstract}

Endothelin (ET) is a 21-amino-acid peptide isolated and characterized from the culture supernatant of porcine aortic endothelial cells (Yanagisawa et al., 1988). The reported biological actions of ET are widespread (for review see Yanagisawa and Masaki, 1989; Simonson and Dunn, 1990; Rubanyi, 1992) but its predominant role in mammals seems to be vasoconstriction. ET is one of the most potent long-lasting vasoconstrictor/pressor substances so far reported. The vasocontractile properties of ET have been shown on isolated mammalian blood vessel preparations (De Nucci et al., 1988) and in vivo at the regional and systemic levels (Miller et al., 1989). ET also induces contraction of nonvascular smooth musculature such as that of the gut wall (De Nucci et al., 1988; Wollberg et al., 1991; Bolger et al., 1992)., Three different mammalian endothelin-related genes have been cloned that correspond to three different endothelins (ET-1, ET-2, and ET-3) that possess similar but not identical 21-residue peptides (Inoue et al., 1989), each produced as a precursor molecule. ET-1 (the originally isolated endothelin), ET-2, and ET-3 were subsequently found in a variety of mammalian tissues (Matsumoto et al., 1989).

In endothelial cells preproET is processed like many other peptide hormones and neuropeptides (Yanagisawa et al., 1988, Itoh et al., 1988). The mature form of ET is generated through the cleavage of a putative intermediate 39-amino-acid precursor called "big-endothelin" (bigET), which is about 140 times less potent than the mature 21-amino-acid peptide in its vasoconstrictor activity (Yanagisawa and Masaki, 1989).

Immunohistochemical evidence of the occurrence of ETs in the endothelial cells was shown initially by Hiroe et al., (1989). Since then, further reports have demonstrated that ET is also expressed in a variety of mammalian cells, including brain and spinal cord neurons (Giaid et al., 1989), bronchial epithelial cells (MacCumber et al., 1989; Rozengurt et al., 1990; Springall et al., 1991), and macrophages (Ehrenreich et al., 1990). There have also been reports of endothelin-like immunoreactivity in endocrine cells, for example, in the human 
pituitary (Naruse et al., 1992), in rat and bovine parathyroid cells (Fujii et al., 1991), and in the cells of the diffuse endocrine system in the human developing lung and gut (Giaid et al., 1990; Gibson et al., 1992; Escrig et al., 1992).

The diffuse endocrine system of the gut of insects is a local regulatory system consisting of several types of endocrine cells spread among the enterocytes. The study of the gut endocrine cells is of particular importance for understanding the regulation of the digestive processes. These endocrine cells, being of a receptosecretory nature, might be involved in the response to the variations of diet composition in terms of control of gut motility and secretion (Simpson and Simpson, 1990), and some are known to react with antibodies directed against mammalian regulatory peptides (Sehnal and Zitnan, 1990; Zitnan et al., 1993). Many of the peptides found in these gut endocrine cells are also present in neurons of the brain or of the segmental ganglia. One of the most investigated peptides in insects is the neuropeptide FMRFamide (FMRFa) which, together with related peptides, is present in both endocrine cells and neurons (Brown and Lea, 1988; Jenkins et al., 1989). In the locust, FMRFa-like peptides have been partially characterized and some of their possible biological roles have already been assessed (Robb and Evans, 1990). The aim of the present investigation was to determine immunohistochemically whether ET-related molecules are present in the endocrine cells of the midgut of the adult and developing desert locust. The possible colocalization of the ET with FMRFa in these endocrine cells has also been studied.

\section{MATERIAL AND METHODS}

In the present study 3 specimens of each posthatching instar and 12 adult locusts of both sexes were used. The locusts were reared according to Barras (1964) at $28^{\circ}$ with a $18: 6 \mathrm{hr}$ photoperiod and fed with grass and bran. To prevent amoebic infections trimetoprime was added to the food. The posthatching development in Locusta migratoria occurs in five instars, previous to the adult stage. Specimens belonging to the different developmental instars can be readily distinguished by observing the anatomy of the alar rudiments, the terminal abdominal segments, and the external genitalia (Uvarov, 1966).

Animals were killed by decapitation and dissected under a Ringer solution isotonic to locust (Schistocerca gregaria) hemolymph (Mordue, 1969). The whole gut was extracted, with the attached Malpighian tubules. The specimens were fixed in Bouin's fluid for $24 \mathrm{hr}$ and embedded in paraffin.

Immunocytochemistry. Paraffin sections (4-6 $\mu \mathrm{m})$ were treated with the avidin-biotin complexes (ABC) technique according to Hsu et al. (1981). After deparaffination with xylol, endogenous peroxidase was blocked by a treatment with $3 \% \mathrm{H}_{2} \mathrm{O}_{2}$ in methanol. Sections were hydrated through alcohols and then placed in Tris- $\mathrm{HCl}$ buffer saline (TBS; $0.05 M$ Tris Buffer, $\mathrm{pH} 7.4,0.5 \mathrm{M} \mathrm{NaCl}$ ). Nonspecific binding sites were blocked with 5\% swine immunoglobulins in TBS. Sections were incubated overnight at $4^{\circ}$ with primary rabbit antiserum (see Table 1). After rinsing in TBS (5 $\mathrm{min}$ ) the sections were incubated for $30 \mathrm{~min}$ at room temperature with biotinylated swine serum directed against rabbit immunoglobulins (Dakopatts, Glostrup, Denmark) diluted 1:200 in TBS. Following a second rinse in TBS, the sections were treated for $30 \mathrm{~min}$ at room temperature with avidin-biotin peroxidase complexes (Dakopatts) diluted 1:100 in TBS and prepared $30 \mathrm{~min}$ in advance. After additional washes, peroxidase was demonstrated by the diaminobenzidine $/ \mathrm{H}_{2} \mathrm{O}_{2}$ method (Sigma Chemical Co., St Louis, MO). Sections were washed with distilled water, lightly counterstained with haematoxylin, dehydrated, and mounted in DPX.

Antisera. Table 1 summarizes the main data concerning the antisera used. The polyclonal antisera

TABLE 1

SURVEY OF THE ANTISERA USED

\begin{tabular}{|c|c|c|}
\hline Antiserum & Dilution & Source and ref no. \\
\hline FMRFa & $1: 3000$ & Peninsula 61009 \\
\hline $\begin{array}{l}\text { ET-1 } \\
\text { (human/porcine) }\end{array}$ & $1: 3000$ & $\begin{array}{l}\text { RPMS }^{a} 1946 \\
\quad(\text { CRB 58) }\end{array}$ \\
\hline $\begin{array}{l}\text { ET-1 } \\
\text { (human/porcine) }\end{array}$ & $1: 1000$ & $\begin{array}{l}\text { RPMS } 1888 \\
\text { (CRB 45) }\end{array}$ \\
\hline $\begin{array}{l}\text { ET-1 } \\
\text { (human/porcine) }\end{array}$ & $1: 1000$ & $\begin{array}{r}\text { RPMS } 1914 \\
\text { (CRB 42) }\end{array}$ \\
\hline ET-1 (15-21) & $1: 2000$ & $\begin{array}{l}\text { RPMS } 2016 \\
\text { (Kimura anti-ETc) }\end{array}$ \\
\hline ET-1 (15-21) & $1: 2000$ & $\begin{array}{l}\text { RPMS } 2085 \\
\quad \text { (Kimura anti-ETc) }\end{array}$ \\
\hline
\end{tabular}

${ }^{a}$ Royal Postgraduate Medical School. 
were raised in New Zealand white rabbits against synthetic whole ET-1 and ET-1 (15-21) (Giaid et al., 1989 Yoshizawa et al., 1990, respectively). Specificity of the immunostaining obtained with these antisera was tested by liquid-phase absorption test $(10 \mathrm{nmol}$ antigen per milliliter of optimally diluted antiserum, $16 \mathrm{hr}$ ) with synthetic whole ET-1 or bigET-1 (Peninsula Labs, Merseyside, UK). The immunostaining with the several antisera against ET-1 was always quenched by the ET-1 molecule. Cross-reactivity of the FMRFa antiserum with ET-1-related molecules and of the ET-1related antisera with FMRFa (Peninsula Labs) was ruled out by means of crossed absorption test. Neither ET-1-like nor FMRFa immunoreactivity was absorbed when bigET-1 peptide was used. As controls for method specificity some sections were incubated with nonimmune rabbit serum instead of the primary antisera. Furthermore, when applicable, one of the stages of the avidin-biotin peroxidase complex procedure was omitted.

Quantification. The quantification studies were performed using the anti-ET-1 antiserum 2085. Four individuals of each of the posthatching stages were used for quantification. Four nonserial sections of the gut of each specimen were counted. To avoid cells appearing in multiple sections, nonserial sections ( 1 every $10 \mathrm{se}$ rial, each one being about $5 \mu \mathrm{m}$ thick) were used for this part of the study. All the immunoreactive cells present in a totally longitudinal section of the midgut were counted. Only the cells with a visible nucleus were considered. The number of cells counted was related either to the total length (in $\mathrm{mm}$ ) of the midgut, from the crop/midgut transition to the pyloric valve, or to the total length of the section of the caecum. Differences in cell density between gut areas and between instar groups were assessed by ANOVA and Scheffe $F$ tests.

\section{RESULTS}

Immunoreactive endocrine cells were present in the midgut of all the specimens studied and were positive for the antibodies raised against FMRFa, ET-1 (1-21), and ET-1 (16-21) (see Table 1)(Figs. 1-9). ET1-like immunoreactivity was clearly evident in cells throughout the whole midgut and caeca. In the ampullae through which the malpighian tubules drain many FMRFaimmunoreactive cells were present, but no ET-1-like immunoreactivity was observed. The ET-1-like immunoreactive cells were frequently found in the vicinity of the nidi of regenerative cells that are spread in the epithelial lining (Figs. 1, 3, and 4) and were also found in between the more differentiated cells of the epithelium. With the antisera used, no ET-1-like immunoreactivity was found in the nerve fibers that innervate the muscle layer of the midgut, while FMRFa immunoreactivity was clearly detectable in many of those fibers (Fig. 2).

ET-1-like immunoreactive cells were elongated or bottle-shaped and usually spanned the whole width of the midgut epithelium from the basal lamina to the lumen (Fig. 1). The cells reached the lumen by means of a thin cytoplasmic process. The total cell size and the size of the nucleus were considerably smaller than those of the neighboring enterocytes. The immunoreactive material was preferentially located in the basal regions of the cell below the nucleus, but was also usually present in the slender apical process that runs toward the lumen.

Colocalization studies were carried out with antibodies 2016 and 1946, respectively directed against ET-1(16-21) and the whole ET-1 molecule, and the antibody against FMRFa. Immunoreactivity with all the ET-1 antisera was detected in the same cells. Using serial reversed-face sections, ET-like immunoreactivity was often found to be colocalized with FMRFa-like immunoreactivity (Fig. 3). In the main segment of the midgut (ventriculus) all the ETimmunoreactive cells were also FMRFaimmunoreactive, although not all the FMRFa-immunoreactive cells present in this region seemed to store ET-like material (Fig. 4). In the midgut caeca there was no apparent correlation between ET-like and FMRFa-immunoreactive cells (Fig. 5). None of the FMRFa-immunoreactive cells that accumulate in the ampullae through which the malpighian tubules drain was labeled by any of the anti-ET-1 antibodies used.

ET-like immunoreactive cells were found in the main region and the caeca of the midgut throughout all the five instars of locust posthatching development (Fig. 10). In the 

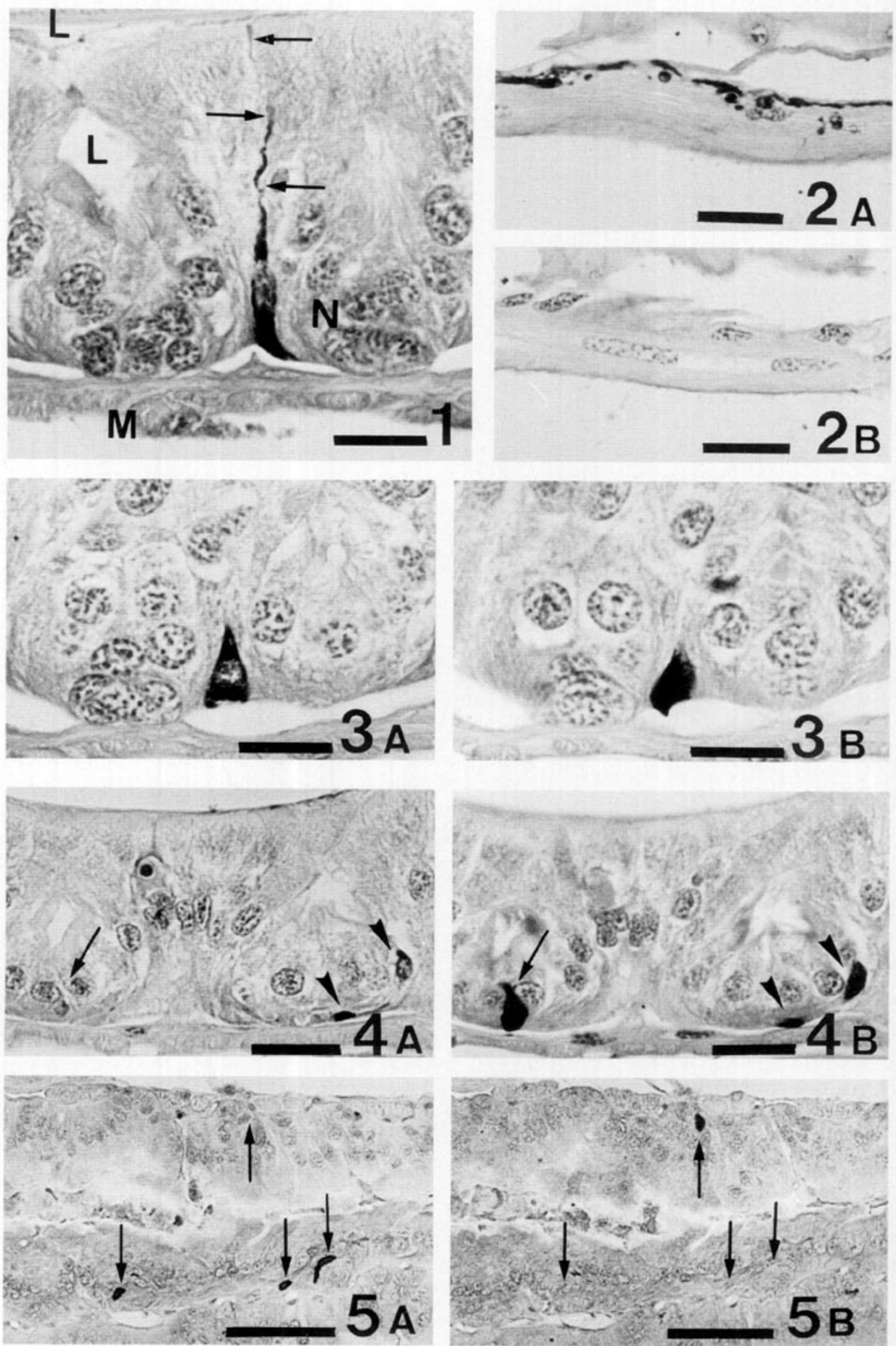
first four instars, the number of ET-like immunoreactive cells was small, frequently not more than 1-2 cells per longitudinal section of the whole gut. The numbers of ETlike immunoreactive cells per unit length of the main region of the midgut increased significantly from the 5 th instar locust $(0.30 \pm$ $0.06 ;$ mean $\pm \mathrm{SEM} ; n=16$ ) to the adult $(1.29 \pm 0.05)(P<0.01)$. In the same stages the density of FMRFa-immunoreactive cells also decreased significantly from 4.16 $\pm 0.22 \mathrm{cells} / \mathrm{mm}$ of midgut to $1.58 \pm 0.07$ cells $/ \mathrm{mm}(P<0.01)$. Similar results were found in the midgut caeca.

Cross-absorption tests (Table 2) did not reveal any cross-reactivity between the antisera against ET-1 and FMRFa and the alternative peptide. In both the main region of the midgut and the midgut caeca, immunoreactivity was not abolished when the anti-ET-1 antibodies were preabsorbed with the tetrapeptide FMRFa (Figs. 6 and 7) or when the anti-FMRFa antiserum was absorbed with ET-1 (Fig. 8). In the same tissue, staining was abolished by preabsorption with ET-1 of antisera 2016 and 2085 against ET-1 (16-21), and 1888, 1946, and 1914 against ET-1 (Figs. 9a and 9b).

\section{DISCUSSION}

In the present work ET-1-like immunoreactivity is shown in endocrine cells of the midgut of the desert locust. The colocaliza- tion of ET-1 in a subpopulation of FMRFaimmunoreactive endocrine cells is also demonstrated.

The use of antisera against vertebrate regulatory peptides has yielded a large number of findings both in the nervous system and in the endocrine cells of invertebrates. The interpretative problems associated with comparative immunohistochemical studies when antibodies directed against molecules from a different species are used have often been stressed and have led to the practice of reporting the positive findings such as peptide-like immunoreactivity. Nevertheless, the structural homology between the amino acid sequences of many vertebrate peptide hormones and the peptides isolated from invertebrate tissues (such as the "peptide families" of insulin, FMRFa, the adipokinetic hormone, proopiomelanocortin, the tachykinins, or gastrin/ CCK; reviewed by De Loof et al., 1990) justifies interest in this kind of immunocytochemical study. The number of vertebrate-related peptides which might have regulatory functions in insects seems to be very high; according to our findings, a molecule structurally related to the newly characterized vertebrate peptide endothelin should be added to this long list.

The antibodies used in the present study have been raised against either the whole mammalian ET-1 molecule or its C-terminal fragment. Our immunocytochemical find-

Fig. 1. ET-immunoreactive endocrine cell located in the basal region of the midgut epithelium. A fine cytoplasmic process (arrows) makes contact with the lumen (L). N, nidus of regenerative cells. M, Muscle cells. Paraffin section. ABC method. Bar; $20 \mu \mathrm{m} . \times 650$.

FIG. 2. Serial reversed-face sections of the muscle layer of the midgut, immunostained for FMRFa (a) and ET (b). The nerve fibers that innervate the muscle layer are stained only when antibodies against FMRFa are used. Bars, $30-\mathrm{m} . \times 400$.

FIG. 3. Serial reversed-face sections of the same endocrine cell, immunoreactive for ET (a) and FMRFa (b). Bars, $20 \mu \mathrm{m}$. $\times 650$.

FIG. 4. Serial reversed-face sections of the main region of the midgut immunostained for ET (a) and FMRFa (b), showing colocalization of both immunoreactivities in two cells (arrowheads). This colocalization does not occur in the FMRFa-immunoreactive cell pointed by the arrow. Bars, $30 \mu \mathrm{m}$. $\times 400$.

FIG. 5. Serial reversed-face sections of the midgut caeca, immunostained for ET (a) and FMRFa (b). No colocalization of these immunoreactivities has been observed in endocrine cells of the midgut caeca (arrows). Bars, $100 \mu \mathrm{m} . \times 150$. 

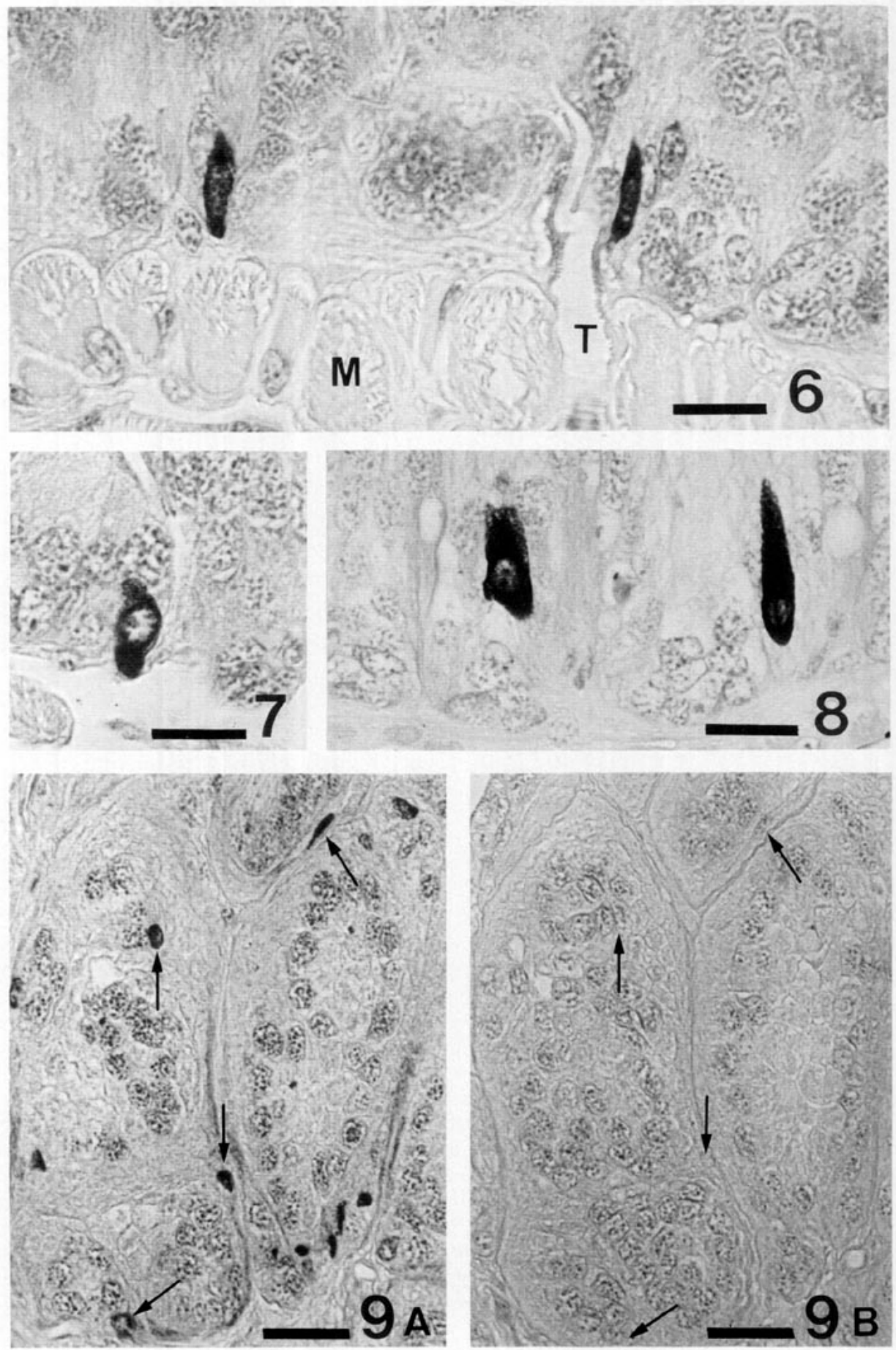


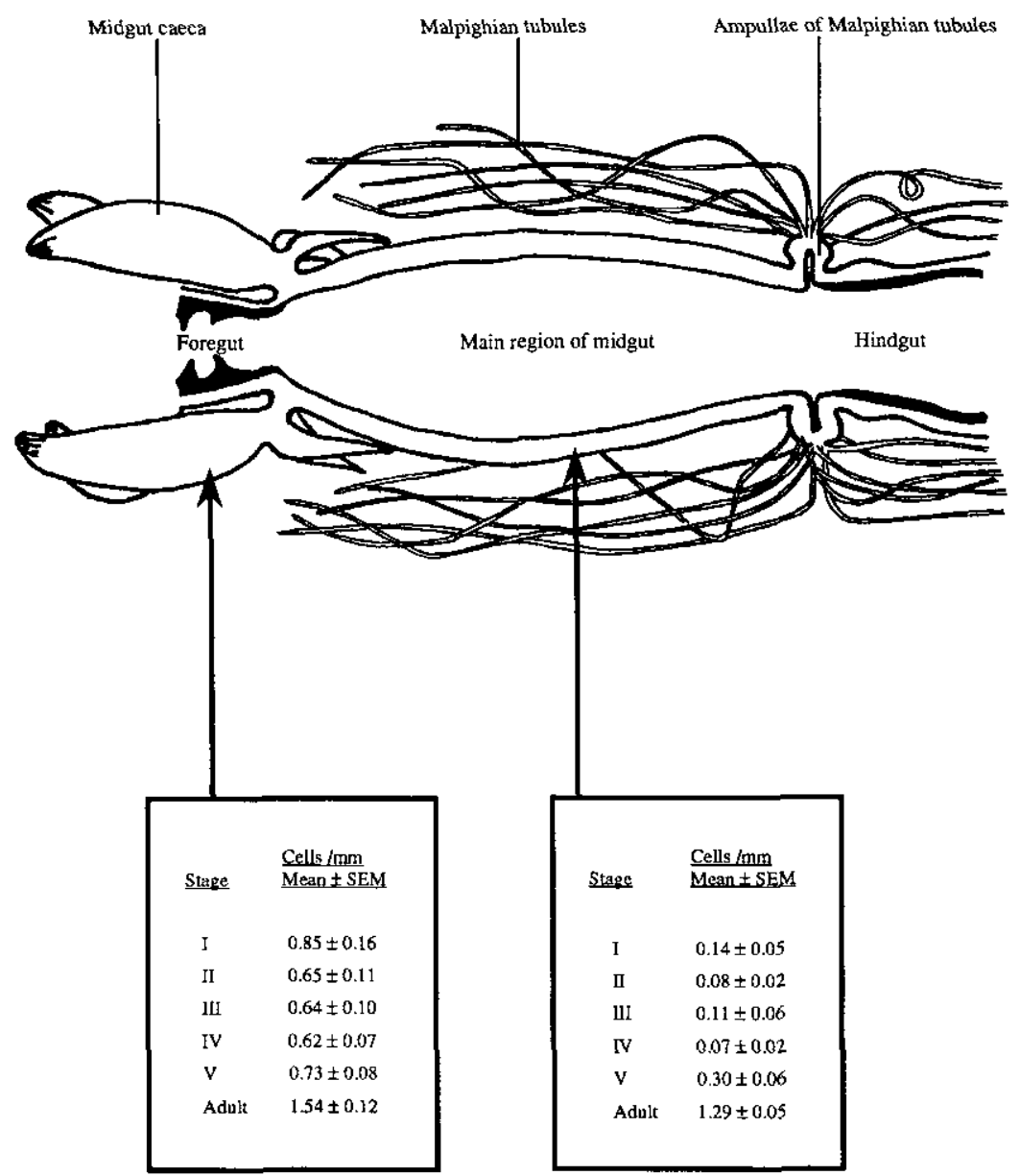

FiG. 10. Distribution of ET immunoreactive cells in the midgut of Locusta migratoria throughout the posthatching developmental stages and in adults. SEM values for the first stages are relatively high due to the numerous zero values (no ET-immunoreactive cell was found in the section).

ings suggest the presence of either ET-1 or at least an antigenically related molecule in a group of endocrine cells of the insect midgut. The positive results obtained in this study using several antibodies against the whole molecule and its $\mathrm{C}$-terminal fragment support the hypothesis of the immunoreactive substance present in these endocrine cells being a truly ET-related molecule or at least a peptide including a sequence very similar to the C-terminal (15-21) amino acids of ET-1.

FIG. 6. Epithelium of the wall of the main region of the midgut immunostained with antibodies against ET absorbed with FMRFa. T, trachea. M, muscle cells. Bar, $20 \mu \mathrm{m} . \times 650$.

FIG. 7. Epithelium of the wall of a midgut caecum immunostained with antibodies against ET absorbed with FMRFa. Bar, $20 \mu \mathrm{m}$. $\times 650$.

FIG. 8. Epithelial layer of the wall of the main region of the midgut, immunostained with antibodies against FMRFa absorbed with ET. Bar, $20 \mu \mathrm{m} . \times 650$.

FIG. 9. Serial sections of the wall of the main region of the midgut, immunostained with antibodies against ET (a) and with the same antiserum absorbed with ET (b). The immunoreactivity in endocrine cells was abolished (arrows). Bars, $30 \mu \mathrm{m}$. $\times 400$. 
TABLE 2

Cross-Absorption Controls

\begin{tabular}{lcc}
\hline & \multicolumn{2}{c}{ Antisera } \\
\cline { 2 - 3 } Peptide & ET-1 & FMRFa \\
\hline ET-1 & - & + \\
bigET-1 & + & + \\
FMRFa & + & - \\
\hline
\end{tabular}

Note. (+) Positive immunoreactivity; (-) negative immunoreactivity.

At present, little is known concerning the evolutionary origins of the endothelins (Landan et al., 1991). In 1989, Kloog et al. reported striking similarities in sequence and bioactivity between ET and a small toxic peptide (sarafotoxin) isolated from the venom from the burrowing asp, Atractaspis engaddensis, and concluded that endothelins and sarafotoxins are members of the same family of peptides. In nonmammalian vertebrates, immunoreactive ET has been detected in the plasma of several species using radioimmunoassay for ET-1 (Udemura et al., 1991). Concerning the invertebrates, there are also some isolated immunocytochemical studies that report immunoreactive endothelin-like substances being found in some central or peripheral neurons of two species of annelids, four species of mollusc, and one species of insect (Kasuya et al., 1990, 1991; Hasegawa and Kobayashi, 1991; Giaid et al., 1991). In the annelid worm Neanthes diversicolor ET-like immunoreactivity was found in several nervous elements, including those innervating the digestive tract (Kasuya et al., 1990). In the species of molluscs studied and in the cricket, the ganglia involved in the visceral innervation contained ETimmunoreactive neurons (Kasuya et al., 1990, 1991; Hasegawa and Kobayashi, 1991; Giaid et al., 1991). In our study, only endocrine cells, and not nerve fibers, were immunostained with the anti ET-1 antibodies, while FMRFa-immunoreactive fibers could be detected. No report has been published so far of endothelin-like immunore- activity in endocrine cells either in nonmammalian vertebrates or in invertebrates.

The presence of an ET-1-like peptide in the diffuse neuroendocrine system of the gut of invertebrates can be related to the already known functional involvement of endothelin in the mammalian gut neuroendocrine system. The immunocytochemical demonstration of ET-1 in the mammalian gut has already been reported (Inagaki et al., 1991; Escrig et al., 1992). ET-1 is the major isoform of endothelin in the adult and fetal human gut along with its precursor form bigET-1. ET-1-like immunoreactivity was found in the gastrointestinal tracts of both adult and fetal gut. Immunocytochemically it was localized to ganglion cells of the gut nervous plexi. Endocrine cells were immunostained for bigET-1 only in some phases of development (Escrig et al., 1992). The possible functional role of endothelin and its precursor in the mammalian gut has been a matter of discussion. Specific binding sites for ET-1 have been demonstrated using in vitro autoradiography in the neural plexi and the mucosa of the human intestine, suggesting a role in the modulation of intestinal motility and secretion (Inagaki et al., 1991). The involvement of endothelin in the regulation of the contraction of gastrointestinal smooth muscle has been shown by several groups (De Nucci et al., 1988; Takahashi et al., 1990; Wollberg et al., 1991; Bolger et al., 1992). Endothelin seems to stimulate ion secretion in stripped intestinal mucosa in a concentrationdependent manner (Brown and Smith, 1991; Roden et al., 1992).

The endocrine cells of the gut of many insects are immunoreactive for FMRFa. FMRFa-like peptides belong to a growing interphyletic family of peptides originally isolated from molluscs (Price et al., 1987). FMRFa and related peptides have potent modulatory actions on locust skeletal and visceral muscle and seem to function both as circulating neurohormones and as locally released neuromodulators and neurotrans- 
mitters (Robb and Evans, 1990). The colocalization of ET and FMRFa supports a possible modulatory interaction between both peptides.

The results of our study lead to the conclusion that there are at least three different endocrine cell types in relation to their immunoreactivity to the antisera used against ET-1 and FMRFa. In the main region of the midgut, ET-1 immunoreactive cells are also immunoreactive with anti-FMRFa. Conversely, in the midgut caeca, the ET-1 immunoreactive cells are not FMRFaimmunoreactive. Finally, in all the three regions of the midgut (caeca, main region, and ampullae of the malpighian tubules) there are FMRFa-immunoreactive cells that are not stained by ET-1 antisera. The interpretation of the different response of FMRFa-immunoreactive cells to ET-1 antisera has to take into account that the antibodies directed against FMRFa most probably recognize a heterogeneous population of endocrine cells. It is known that the antiFMRFa antisera are able to react with a variety of different peptides belonging to the same family containing an identical or similar C-terminal sequence. In insects, several neuropeptides belonging to this family have already been isolated (Holman et al., 1986; Nambu et al., 1988; Schneider and Taghert, 1988) mainly from the brain but also from the abdominal ganglia (Duve et al., 1992).

Escrig et al. (1992) suggested that the presence of endothelin-related immunoreactivity in the endocrine cells of the mammalian gut mucosa during development may be related to the reported role of endothelins on the stimulation of cell division and on growth (Brown and Littlewood, 1989; Bobik et al., 1990). Our quantitative study of the distribution of cells throughout the development of the posthatching locust shows that in the adults there is an increased number of ET-1-like immunoreactive cells per area of midgut tissue sectioned compared to the rest of the develop- ing instars. Thus, in the case of the locust, the immunoreactivity for ET-1 is sparse in the phases of development in which the growth in size of the gut is taking place. There are several possibilities to explain the scarcity of ET-1-like immunoreactivity in the first instars. It could be due either to a low number of ET-1-like producing cells or to a nondetectable amount of ET-1 being produced, or to an increase in the release of the peptide. In the same way, the higher proportion of cells in the adults could be due either to an increased rate of differentiation of the ET-1-like cells from the regenerative nidi from where they originate (Endo et al., 1983; Montuenga et al., 1989), or alternatively to an increased storage of the peptide that renders more cells detectable with our immunocytochemical methods. The comparison of the quantitative data of the ET-like immunoreactive cell population with those of the FMRFa population gives some help in the clarification of the questions posed above. Our data show that, while the population of detectable FMRFa cells seems to be decreased when entering the adult stage, there is an apparent increase in the number of ETimmunoreactive cells, making the hypothesis of increased storage of the ET-1-like material more likely than that of an increased rate of endocrine cell differentiation. Moreover, the very few data available on the kinetics of the adult insect midgut point toward a slow mechanism of differentiation from the nidi as the way of appearance of new endocrine cells. In the gut of the adult cockroach, it takes between 7 and 14 days from the end of cell division for a precursor cell to acquire PP-like immunoreactivity (Endo et al., 1983). If the rate of differentiation of ET-1-like immunoreactive cells from the nidi in the developing locust is similar to that measured for the PP-like cells of adult cockroaches, the sharp rise of endothelin-1-like immunoreactivity shown in our study could very unlikely be due to a process of differentiation of new cells. Fur- 
ther experiments are required to correlate cell proliferation with the pattern of immunoreactivity and, eventually, to define whether the rise in ET-1 storage suggested for the adult stage is produced either by a lack of release or by an increased synthesis of the peptide.

Until the immunoreactive materials present in the midgut endocrine cells are fully characterized, it is too speculative to assess the physiological role of the endogenous endothelin-like peptides in L. migratoria and in other insect species. The precise functions of these peptides in the endocrine cells of the insect midgut remain to be elucidated.

\section{ACKNOWLEDGMENTS}

This work has been supported by EC Grant SCICT90-0480 and by Grant CE91-0002 of the Spanish DGICYT. We acknowledge the technical help of Miss Isabel Ordoqui and the generous gift of the C-terminal endothelin antiserum by Professor S. Kimura, University of Tsukuba, Japan.

\section{REFERENCES}

Barras, R. (1964). "The Locust: A Guide for Laboratory Practical Work." Butterworths, London.

Bobik, A., Grooms, A., Millar, J. A., Mitchell, A., and Grinpukel, S. (1990). Growth factor activity of endothelin on vascular smooth muscle. Am. $J$. Physiol. 258, C408-C415.

Bolger, G. T., Liard, F., Garneau, M., and Jaramillo, J. (1992). Characterization of intestinal smooth muscle responses and binding sites for endothelin. Can. J. Physiol. Pharmacol. 70(3), 377-384.

Brown, K. D., and Littlewood, C. J. (1989). Endothelin stimulates DNA synthesis in Swiss 3T3 cells; Synergy with polypeptide growth factors. Biochem. J. 263, 977-980.

Brown, M. A., and Smith, P. L. (1991). Endothelin: A potent stimulator of intestinal ion secretion in vitro. Regul. Pept. 36(1), 1-19.

Brown, M. R., and Lea, A, O. (1988). FMRFamideand adipokinetic hormone-like immunoreactivity in the nervous system of the mosquito, Aedes aegypti. J. Comp. Neurol. 270, 606-614.

DeLoof, A., Schoofs, L., and Vanden Broeck, J. (1990). Molecular structures of some vertebratetype messenger peptides in invertebrates. In "Progress in Comparative Endocrinology (Epple, Scanes, and Stetson, Eds.), Vol. 342, pp. 16-21. Wiley-Liss, New York.
DeNucci, G., Thomas, R., D'Orleans-Juste, P., Autunes, E., Walder, C., Warner, T. D., and Vane, J. R. (1988). Pressor effects of circulating endothelin are limited by its removal in the pulmonary circulation and by the release of prostacyclin and endothelium-derived relaxing factor. Proc. Natl. Acad. Sci. USA 85, 9797 -9800.

Duve, H., Johnsen, A. H., Sewell, J. C., Scott, A. G., Orchard, I., Rehfeld, J. F., and Thorpe, A. (1992). Isolation, structure and activity of PheMet-Arg-Phe- $\mathrm{NH}_{2}$ neuropeptides designated calliFMRFamides from the blowfly Calliphora vomitoria. Proc. Natl. Acad. Sci. USA 89, 23262330.

Ehrenreich, H., Anderson, R. W., and Fox, C. M. (1990). Endothelins, peptides with potent vasoactive properties, are produced by human macrophages. J. Exp. Med. 172, 1748-1748.

Endo, Y. Sugihara, H., Fujita, S., and NishiitsutsujiUwo, J. (1983). Kinetics of columnar and endocrine cells in the cockroach midgut. Biomed. Res. 4(1), 51-60.

Escrig, C., Bishop, A. E., Inagaki, H., Moscoso, G., Takahashi, K., Varndell, I. M., Ghatei, M. A., Bloom, S. R., and Polak, J. M. (1992). Localisation of endothelin-like immunoreactivity in adult and developing human gut. Gut 33(2), 212-217.

Fujii, Y., Moreira, E., Orlando, C., Maggi, M., Aurbach, G. D., Brandi, M. L., and Sakaguchi, K. (1991). Endothelin as an autocrine factor in the regulation of parathyroid cells. Proc. Natl. Acad. Sci. USA 88, 4235-4239.

Giaid, A., Gibson. S. J., Ibrahim, N. B. N., Legon, S., Bloom, S. R., Yanagisawa, M., Masaki, T., Varndell, I. M., and Polak, J. M. (1989). Endothelin-1, and endothelium-derived peptide, is expressed in neurons of the human spinal cord and dorsal root ganglia. Proc. Natl. Acad. Sci. USA 86, 7634-7638.

Giaid, A., Hamid, Q. A., Springall, D. R., Yanagisawa, M., Shinmi, O., Sawamura, T., Masaki, T., Kimura, S., Corrin, B., and Polak, J. M. (1990). Detection of endothelin immunoreactivity and mRNA in pulmonary tumors. J. Pathol. 162(1), 15-22.

Giaid, A., Masaki, T., Ouimet, T., Yanagisawa, M., Gaspar, L., Cantin, M., Kimura, S., and Castellucci, V. F. (1991). Expression of endothelin-like peptide in the nervous system of the marine mollusk Aplysia. J. Cardiovasc. Pharmacol. 17 (Suppl. 7), S449-S451.

Gibson, S. J., Springall, D. R., and Polak, J. M. (1992). Endothelin, a ubiquitous peptide: Morphological demonstration of immunoreactive and synthetic sites and receptors in the respiratory tract and central nervous system. In "Endothelin" 
(Rubanyi, ed.). American Physiological Society. Oxford Univ. Press, New York/Oxford.

Hasegawa, K., and Kobayashi, H. (1991). Immunohistochemical localization of endothelin-1 in the nervous system of the earth-worm Eisenia foetida. Gen. Comp. Endocrinal. 81, 433-441.

Hiroe, M., Hirata, Y., Marumo, F., Nagata, M., Toyozaki, T., Hasumi, M., Ohta, Y., Horie, T., and Sekiguchi, M. (1989). Immunohistochemical localization of endothelin in human vascular endothelial cells. Peptides 10, 1281-1282.

Holman, G. M., Cook, B. J., and Nachman, R. J. (1986). Isolation, primary structure and synthesis of leucomyosuppresin, an insect neuropeptide that inhibits spontaneous contractions of the cockroach hindgut. Comp. Biochem. Physiol. 85C, 329-333.

Hsu, S. M., Raine, L., and Fanger, H. (1981). Use of avidin-biotin-peroxidase complex $(\mathrm{ABC})$ in immunoperoxidase techniques: A comparison between $\mathrm{ABC}$ and unlabeled antibody (PAP) procedures. J. Histochem. Cytochem. 29, 577.

Inagaki, H., Bishop, A. E., Escrig, C., Wharton, J., . Allen-Mersh, T. G., and Polak, J. M. (1991). Localization of endothelin-like immunoreactivity and endothelin binding sites in human colon. Gastroenterology 101(1), 47-54.

Itoh, Y., Yanagisawa, M., Ohkubo, S., Kimura, C., Kosaca, T., Inone, A., Ishida, N., Mitsui, Y., Onda, H., Fugino, M., and Masaki, T. (1988). Cloning and sequence analysis of cDNA encoding the precursor of a human endothelium-derived vasoconstrictor peptide, endothelin: Identity of human and porcine endothelin. FEBS Lett. 231, 440-444.

Jenkins, A. C., Brown, M. R., and Crim, J. W. (1989). FMRFamide immunoreactivity and the midgut of the corn earworm (Heliothis zea). J. Exp. Zool. 252, 71-78.

Kasuya, Y., Kobayashi, H., and Uemura, H. (1990). The distribution of an immunoreactive endothelin-like substance in the nervous system of the nereid, Neanthes diversicolor (annelida). Cell Tissue Res. 261, 485-492.

Kasuya, Y., Kobayashi, H., and Uemura, H. (1991). Endothelin-like immunoreactivity in the nervous system of invertebrates and fish. $J$. Cardiovasc. Pharmacol. 17 (Suppl. 7), S463-S466.

Kloog, Y., and Sokolovsky, M. (1989). Similarities in mode and sites of action of sarafotoxins and endothelins. Trends. Pharmacol. Sci. 10, 212-214.

Landan, G., Bdolah, A., Wollberg, Z., Kochva, E., and Graur, D. (1991). The evolutionary history of the sarafotoxin/endothelin/endothelin-like superfamily. J. Cardiovasc. Pharmacol 17 (Suppl. 7), S517-\$519.

MacCumber, M. W., Ross, C. A., Glaser, B. M., and
Synder, S. H. (1989). Endothelin: Visualization of mRNAs by in situ hybridization provides evidence for local action. Proc. Natl. Acad. Sci. USA 86, 7285-7289.

Matsumoto, H., Suzuki, N., Onda, H., and Fujino, M. (1989). Abundance of endothelin-3 in rat intestine, pituitary gland and brain. Biochem. Biophys. Res. Commun. 164(1), 74-80.

Miller, W. L., Redfield, M. M., and Burnett, J. C., Jr. (1989). Integrated cardiac, renal, and endocrine actions of endothelin. J. Clin. Invest. 83(1), 317320 .

Montuenga, L. M., Barrenechea, M. A., Sesma, P., López, J., and Vázquez, J. J. (1989). Ultrastructure and immunocytochemistry of endocrine cells in the midgut of the desert locust, Schistocerca gregaria (forskal). Cell Tissue Res. 258, 577-583.

Mordue, W. (1969). Hormonal control of Malpighian tube and rectal functions in the desert locust Schistocerca gregaria. J. Insect. Physiol. 15, 273.

Nambu, J. R., Murphy-Erdosh, C., Andrews, P. C., Feistner, G. J., and Scheller, R. H. (1988). Isolation and characterization of a Drosophila neuropeptide gene. Neuron 1, 53-61.

Naruse, M., Naruse, K., Nishikawa, T., Yoshihara, I., Ohsumi, K., Suzuki, N., Demura, R., and Demura, H. (1992). Endothelin-3 immunoreactivity in gonadotrophs of the human anterior pituitary. J. Clin. Endocrinol. Metab. 74(5), 968-972.

Price, D. A., Davies, N. W., Doble, K. E., and Greenberg, M. I. (1987). The variety and distribution of the FMRFamide-related peptides in molluscs. Zool. Sci. 4, 395-410.

Robb, S., and Evans, P. D. (1990). FMRFamide-like peptides in the locust: Distribution, partial characterization and bioactivity. J. Exp. Biol. 149, $335-360$.

Roden, M., Plass, H., Vierhapper, H., and Turnheim, K. (1992). Endothelin-1 stimulates chloride and potassium secretion in rabbit descending colon. Pflugers Arch. 421, 2-3.

Rozengurt, N., Springall, D. R., and Polak, J. M. (1990). Localization of endothelin-like immunoreactivity in airway epithelium of rats and mice. $J$. Pathol. 160, 5-8.

Rubanyi, M. G. (1992). "Endothelin." American Physiological Society. Oxford Univ. Press, New York/Oxford.

Schneider, L. E., and Taghert, P. H. (1988). Isolation and characterization of a Drosophila gene that encodes multiple neuropeptides related to Phe-Met-

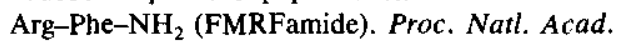
Sci. USA 85, 1993-1997.

Sehnal, E., and Zitnan, D. (1990). Endocrines of insect gut. In "Progress in Comparative Endocrinology" (Epple, Scanes, and Stetson, Eds.), Vol. 342 , pp. 510-515. Wiley-Liss, New York. 
Simonson, M. S., and Dunn, M. J. (1990). Endothelin: Pathways of transmembrane signaling. Hypertension 15 (Suppl.I), I-5-I-12.

Simpson, S. J., and Simpson, C. L. (1990). The mechanisms of nutritional compensation by phytophagous insects. In "Insect-Plant Interactions" (E. A. Bernays, Ed.) Vol. II, pp. 111-160. CRC Press, Boca Raton, FL.

Springall, D. R., Howarth, P. H., Couniham, H., Djukanovic, R., Holgate, S. T., and Polak, J. M. (1991). Endothelin immunoreactivity of airways epithelium in asthmatic patients. Lancet 337, 697-701.

Uemura, H., Naruse, M., Naruse, K., Hirohama, T., Demura, H., and Kasuya, Y. (1991). Immunoreactive endothelin in plasma of nonmammalian vertebrates. J. Cardiovasc. Pharmacol. 17 (Suppl. 7), S414-S416.

Uvarov, B. (1966). "Grasshoppers and Locusts: A handbook of General Acridology," Vol. I. Cambridge Univ. Press, London.

Wollberg, Z., Bdolah, A., Galron, L., Sokolovsky, M., and Kochva, E. (1991). Contractile effects and binding properties of endothelins/sarafotoxins in the guinea pig ileum. Eur. J. Pharmacol. 198(1), 31-36.

Yanagisawa, M., Kurihara, M., Kimura, S., Tomobe, Y., Kobayashi, M., Mitsui, Y., Yazaki, Y., Goto, K., and Masaki, T. (1988). A novel potent vasoconstrictor peptide produced by vascular endothelial cells. Nature 332, 411-415.

Yanagisawa, M., and Masaki, T. (1989). Endothelin, a novel endothelium-derived peptide: Pharmacological activities, regulation and possible roles in cardiovascular control. Biochem. Pharmacol. 38(12), 1877-1883.

Yoshizawa, T., Shinmi, O., Giaid, A., Yanagisawa, M., Gibson, S. J., Kimura, S. Uchiyama, Y., Polak, J. M., Masaki, T., and Kanazawa, I. (1990). Endothelin: A novel peptide in the posterior pituitary system. Science 247, 462-464.

Zitnan, D., Sauman, I., and Sehnal, F. (1993). Peptidergic innervation and endocrine cells of insect midgut. Arch. Insect Biochem. Physiol. 22, 1-2. 